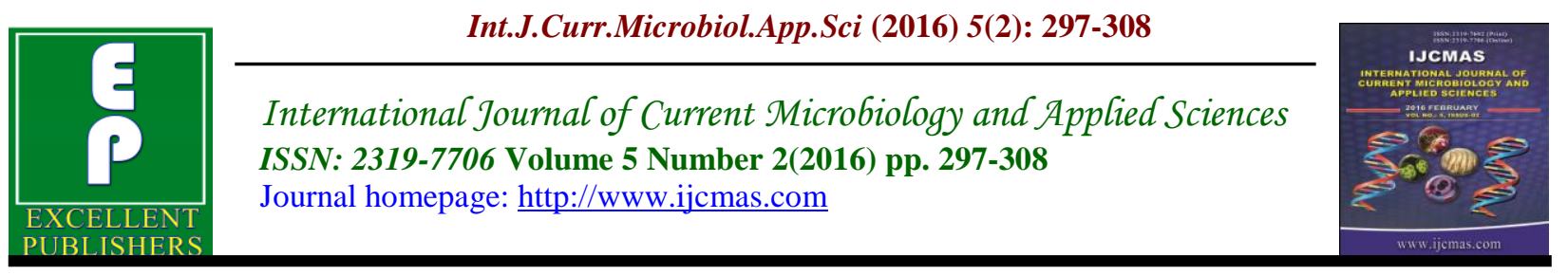

Original Research Article

doi: http://dx.doi.org/10.20546/ijcmas.2016.502.034

\title{
Purification and Biochemical Characteristic of Protease from the Red Seaweed Petrocladia capillacea
}

\author{
Hamed M El-Shora*, G.S. Abou-El-Wafa and A.I. Kadhim \\ Botany Department, Faculty of Science, Mansoura University, Egypt \\ *Corresponding author
}

\begin{tabular}{|c|c|}
\hline & A B S T R A C T \\
\hline Keywords & \multirow{5}{*}{$\begin{array}{l}\text { The aims of the present work was to purify protease enzyme from the redsea } \\
\text { weed Petrocladia capillacea. Protease was purified by } 70 \% \text { ammonium } \\
\text { sulfate and Sephadex } \mathrm{G}-200 \text {. The specific activity was } 280 \text { units } \mathrm{mg}^{-1} \\
\text { protein and with } 122 \text {-fold.The optimal casein concentration was } 40 \%(\mathrm{w} / \mathrm{v}) \text {. } \\
\text { The } \mathrm{K}_{\mathrm{m}} \text { and } \mathrm{V}_{\max } \text { values were } 52.6 \%(\mathrm{w} / \mathrm{v}) \text { and } 33.3 \text { units } \mathrm{mg}^{-1} \text { protein. The } \\
\text { final incubation time was } 40 \mathrm{~min} \text {. The optimal } \mathrm{pH} \text { and optimal temperature } \\
\text { were } 7 \text { and } 40^{\circ} \mathrm{C} . \mathrm{Ca}^{+2} \text { and } \mathrm{Mg}^{+2} \text { were the best activator divalent cations. The } \\
\text { other cations } \mathrm{Hg}^{2+}, \mathrm{Cu}^{2+}, \mathrm{Al}^{3+}, \mathrm{Co}^{2+} \text { and } \mathrm{Zn}^{2+} \text { were inhibitors. Protease was } \\
\text { activated by the amino acids cysteine and methionine. However, protease } \\
\text { was activated by reduced glutathione, thiourea, thioglycolate, and acetyl } \\
\text { cysteine. }\end{array}$} \\
\hline $\begin{array}{l}\text { Petrocladia } \\
\text { capillacea, } \\
\text { Biochemical } \\
\text { Characteristic } \\
\text { of Protease }\end{array}$ & \\
\hline Article Info & \\
\hline $\begin{array}{l}\text { Accepted: } \\
\text { 15 January } 2016\end{array}$ & \\
\hline $\begin{array}{l}\text { Available Online: } \\
\text { 10, February } 2016\end{array}$ & \\
\hline
\end{tabular}

\section{Introduction}

Seaweeds are multicellular macroalgae used as a potential renewable resource in the field of medical and commercial environment. Many seaweeds have commercial applications in pharmaceutical, medical, cosmetic, nutraceutical, food and agricultural industries (Torres et al., 2014).

Seaweeds are very common for people since they is rich in vitamins and minerals mainly calcium, sodium, magnesium, potassium, iodine, iron, and zinc (Lopez et al., 2009; Caliceti et al., 2001).

Enzymes are biocatalysts that been used as alternatives to chemicals to improve the efficiency and cost-effectiveness of a wide range of industrial processes.
They are currently used in applied and basic areas of research as well as in a wide range of products and manufacturing processes, such food, beverage, detergent, pharmaceutical, leather processing and peptide synthesis industries (Gupta et al., 2002).

Proteases have a wide distribution in plants (Sharmila et al., 2012), microorganisma (Maghsoodi et al., 2013) and seaweed (Patil and Rebecca, 2014).

Proteases constitute about $70 \%$ of industrial enzyme alone and microbial sources are leading supplier of these enzyme. These enzymes possess catalytic activity in broad 
range of temperature and $\mathrm{pH}$ (Murakami et al., 1991; Sanatan et al., 2013).

The protease is also called as peptidase or proteinase is group of enzyme that performs hydrolysis of the peptide bonds that link amino acids together in the polypeptide chain forming the protein(Hedstrom, 2002).

The present work aimed to purify protease from the red seaweed Petrocladia capillacea. It is also aimed to study the biochemical characteristics of the enzyme.

\section{Materials and Methods}

\section{Collection of Seaweed}

Petrocladia capillacea samples were collected by hand from submerged rocks on the coast of Abu Qir Bay, Alexandria, Egypt. After collection, the samples were transported to the laboratory in plastic bags containing sea water to prevent evaporation

\section{Cleaning of Algae}

The algal samples then cleaned from epiphytes and rock debris then rinsed many times in distilled water to remove surface salts. Some of the collected samples were preserved for identification. The seaweed was identified following Aleem (1993).

\section{Preparation of Algal Protease Extract}

Afresh sample $(0.5 \mathrm{~g})$ of algae was suspended in $100 \mathrm{ml}$ phosphate buffer $(\mathrm{pH}$ 7.0) the buffer containing $1 \mathrm{mM}$ dithiothreitol, $10 \mathrm{mM}$ glycine and processed for $10 \mathrm{~min}$ in pestle and mortar. The resulting homogenates were then pooled and filtered through cheesecloth the filtrate is used as crude extract.

\section{Assay of Algal Protease}

The purified enzyme $(0.5 \mathrm{ml})$ was mixed with $0.5 \mathrm{ml}$ casein. The reaction mixture was incubated for $1 \mathrm{~h}$ at $40^{\circ} \mathrm{C}$ and stopped by addition of $1 \mathrm{ml}$ of $15 \%$ TCA. The mixture was then centrifuged and supernatant was collected. The supernatant was mixed with $\mathrm{Na}_{2} \mathrm{CO}_{3}$ and $\mathrm{NaOH}$ and Folin Phenol. This mixture was shaken and the absorbance was taken at $650 \mathrm{~nm}$. One protease unit was defined as the amount of enzyme that releases $0.5 \mu \mathrm{g} / \mathrm{ml} / \mathrm{min}$ tyrosine. The protease activity was measured spectrophotometrically.

\section{Determination of Protein Content}

Soluble protein content was determined as described by Bradford (1976). Ten $\mathrm{g}$ of Petrocladia capillacea were homogenized in $100 \mathrm{mM}$ phosphate buffer $\mathrm{pH}$ (7.0). The extract was centrifuged for $30 \mathrm{~min}$ at 6,000 $\mathrm{rpm}$. One $\mathrm{ml}$ of supernatant was added to $5 \mathrm{ml}$ diluted Coomassie Brillant Blue G-250 and vigorously mixed. After keeping it in the dark for $1 \mathrm{~min}$, the absorption of the protein in the extract at $595 \mathrm{~nm}$ was spectrophotometrically measured. The protein concentration was determined from standard curve using bovine serum albumin.

\section{Purification of Algal Protease}

\section{Ammonium Sulphate Fractionation}

The crude algal was homogenated with ammonium sulphate. The supernatant was saturated up to $70 \%$ with $\left(\mathrm{NH}_{2}\right)_{2} \mathrm{SO}_{4}$ under continuous at $\mathrm{pH}$ 7.The suspension was centrifuged at $8,000 \mathrm{~g}$ for $15 \mathrm{~min}$ at $0-4^{\circ} \mathrm{C}$. The pellet obtained was dissolved in extraction buffer (20 mM, pH 7.0). The final volume was made up to $10 \mathrm{ml}$. This fraction was extensively dialyzed using dialysis tube with continuous stirring for 24 hours at 0 $4^{\circ} \mathrm{C}$ against the same buffer.

\section{Gel filtration chromatography}

The dialyzed extract was further purified 
using filtration chromatography (Sephadex G-200). The Sephadex beads were activated using extraction buffer for 72 hours with washing several times. Activated beads were poured slowly in glass chromatography column with the help of a glass rod to avoid trapping of air bubbles. Eluents were collected in different fraction tubes of $1 \mathrm{ml}$. The fractions containinghigher activity were pooled were diluted with extraction buffer according to need. The obtained enzyme was stored at $0-4^{\circ} \mathrm{C}$ and used throughout this study.

\section{Estimation of Kinetic Parameters}

The Michaelis-Menten constant $\left(\mathrm{K}_{\mathrm{m}}\right)$ and the maximum velocity $\left(\mathrm{V}_{\max }\right)$ were determined by investigating the effect of casein concentration on enzyme activity. Enzyme activity was determined at different casein concentrations $(10-50 \% \mathrm{w} / \mathrm{v})$. The Lineweaver-Burk plot (1/ Vagainst 1/ S, where $\mathrm{V}$ is the reaction velocity) was then constructed. The $\mathrm{K}_{\mathrm{m}}$ and $\mathrm{V}_{\max }$ were determined for algal protease from this graph.

\section{Effect of pH on Algal Protease}

The optimal $\mathrm{pH}$ for enzyme activity was investigated over a range from 4-10. Sodium acetate/acetic ( $\mathrm{pH} 3.0-4.0$ - 5.0), potassium phosphate buffer $(6.0-7.0)$, Tris- $\mathrm{HCl}$ buffer $(8.0-9.0)$ and sodium bicarbonate buffer (10.0) were used. From the results obtained a graphic of enzyme activity $v s \mathrm{pH}$ was plotted, and the optimum $\mathrm{pH}$ for algal protease was determined.

\section{Effect of Temperature on Algal Protease}

Reaction mixture was incubated at different temperatures $20,30,40,50,60,30{ }^{\circ} \mathrm{C}$. The optimum temperature was determined from the graphic of enzyme activity against. The enzyme activity was estimated by the method described above.

\section{Effect of Metal Cations on Algal Protease}

The effect of divalent cations $\mathrm{Mg}^{+2}, \mathrm{Ca}^{+2}$, $\mathrm{Co}^{+2}, \mathrm{Zn}^{+2}, \mathrm{Al}^{+2}, \mathrm{Cu}^{+2}$ and $\mathrm{Hg}^{+2}$ (in the form of their chlorides) at $5 \mathrm{mM}$ on the activity of the algal protease was studied by including them in the standard reaction mixture containing the enzyme and casein as substrate. The control was done with enzyme without metals.

\section{Effect of Amino acids on Algal Protease}

The effect of the amino acids cysteine, methionine, lysine, glutamic acid, arginine, tyrosine and glutamine on protease activity was carried out in the reaction mixture at 5 $\mathrm{mM}$.

\section{Effect of Thiol Compounds on Algal Protease}

The effect of the thiol compounds reduced glutathione (GSH), thiourea, thioglycolate, and acetyl cysteine on algal protease was investigated in the reaction mixture. GSH was tested at 10-50 mM, however thiourea, thioglycolate and acetyl cysteine were tested at $20-100 \mathrm{mM}$.

\section{Results and Discussion}

\section{Purification of Algal Protease}

Protease was purified from Petrocladia capillacea by ammonium sulfate and Sephadex G-200 with specific activity of 280 units $\mathrm{mg}^{-1}$ protein with 122 -fold (Table 1).Protease from Bacillus amyloliquefaciens H11 was purified with 16-fold (Sai-Ut et al., 2015).

\section{Effect of Casein on Protease Activity}

The effect of casein concentration $(\% \mathrm{w} / \mathrm{v})$ on protease activity was investigated. The tested concentrations $(10,20,30,40$, and 50 
$(\% \mathrm{w} / \mathrm{v})$.The results in Fig. 1indicate that by increasing the casein concentration thease was continous increase in the activity up to $40 \%$ (w/v) ofter which there was steady increase at $50 \%(\mathrm{w} / \mathrm{v}) . \mathrm{K}_{\mathrm{m}}$ was $52.6 \% \mathrm{w} / \mathrm{v}$ and $\mathrm{V}_{\max }$ was 33.3 units $\mathrm{mg}^{-1}$ protein (Fig. 2).

\section{Effect of pH on Protease Activity}

The results in Fig. 3 show the optimal pH value was 7.0. These results are in harmony with those reported for the enzyme from Ulva fasciata (Patil and Rebecca, 2014) andUlva pertusa (Kang et al., 2015). Jellouli et al. (2011) similarly reported the optimum $\mathrm{pH}$ to be 7.0 for protease activity. The importance of neutral proteases are their application in the food industry, because they perform specific function reducing the bitterness of food protein hydrolysates through hydrolyzing hydrophobic amino acid bonds at neutral $\mathrm{pH}$ (Sandhya et al. 2005). However, optimal pH 9.0 was reported for the enzyme from Bacillus subtilis (Naidu, 2011).

\section{Effect of Temperature on Protease Activity}

In this experiment of temperature $(20,30$, $40,50,60$, and $70{ }^{\circ} \mathrm{C}$ )on protease activity was investigated. The results in Fig.4 indicate that there was continuous increase in the enzyme activity with increasing the temperature up to $40^{\circ} \mathrm{C}$ after which the activity declined at 50, 60 and $70^{\circ} \mathrm{C}$. Therefore, the optimal temperature was $40^{\circ} \mathrm{C}$. The results are consistent with those of for the enzyme from Ulva fasciata (Patil and Rebecca, 2014)Ulva pertusa (Kang et al., 2015). However, optimum temperature of $60{ }^{\circ} \mathrm{C}$ was reported for the enzyme from Bacillus subtilis (Naidu, 2011).

\section{Effect of Incubation Time on Protease Activity}

In this experiment the relation between incubation time and protease activity was investigated. The protease activity was assayed throughout various time intervals $(10,20,30,40,50$, and $60 \mathrm{~min})$. The results in Fig.5show that there was a corresponding increase in the enzyme activity with increasing the time. The optimum time was $40 \mathrm{~min}$ after witch the activity declined gradually.

\section{Effect of Metal Ions on Protease Activity}

The effect of metals ions $\mathrm{Ca}^{+2}, \mathrm{Al}^{+3}, \mathrm{Mg}^{+2}$, and $\mathrm{Zn}^{+2}$ on protease activity. These cations were tested at $5 \mathrm{mM}$. The results in Fig.6indicate that cation $\mathrm{Ca}^{+2}$ and $\mathrm{Mg}^{+3}$ activated the protease activity. The $\mathrm{Ca}^{+2}$ was better activator than $\mathrm{Mg}^{+2}$. This in accordance with the results of Ahmetoglu et al. (2015) for the enzyme from Bacillus sp. KG5.

Adinarayana et al. (2003), Hmidet et al. (2009) and Annamalai et al. (2014) stated that $\mathrm{Ca}^{2+}$ acts as an activator for proteases. The increase in the activity in the presence of $\mathrm{Ca}^{2+}$ may be attributed to stabilisation of enzymes in its active conformation rather than it being involved in the catalytic reaction. It may possibly acts as a salt or an ion bridge via a cluster of carboxylic groups (Divakar et al. 2010). The other remining metal ions inhibited the activity. The inhibition of protease by $\mathrm{Cu}^{+2}$ and $\mathrm{Zn}^{+2}$ is similar to the enzyme from Ulva pertusa (Kang et al., 2015).The protease from Brevibacillus (Bacillus brevis) was also inhibited by $\mathrm{Hg}^{2+}, \mathrm{Zn}^{2+}$ and $\mathrm{Cu}^{2+}$ (Banerjee $e t$ al., 1999). These metal ions chemically react with the protein thiol-group in addition to tryptophan and histidine amino acid in the polypeptide chain of enzyme. Furthermore, the disulphide bonds were noted to hydrolytically breakdown in the presence of mercury and silver metal ions (Ladenstein and Antranikian, 1998). 
Table.1 Purification Steps of Neutral Protease from Petrocladia capillacea

\begin{tabular}{|l|l|l|l|l|l|}
\hline Purification steps & $\begin{array}{l}\text { Total } \\
\text { activity } \\
\text { (Units) }\end{array}$ & $\begin{array}{l}\text { Total } \\
\text { protein } \\
\text { (mg) }\end{array}$ & $\begin{array}{l}\text { Specific } \\
\text { activity } \\
\text { (U/mg) }\end{array}$ & $\begin{array}{l}\text { Fold } \\
\text { of } \\
\text { purification }\end{array}$ & $\begin{array}{l}\text { Yield } \\
(\%)\end{array}$ \\
\hline $\begin{array}{l}\text { Crude enzyme } \\
\text { 70\% Ammonium } \\
\text { sulfate } \\
\text { Sephadex-G200 }\end{array}$ & 644 & 280 & 2.3 & 1 & 100 \\
6 & 4.0 & 68.5 & 29.8 & 42.5 \\
\hline
\end{tabular}

Fig.1 Effect of Casein Concentration on Neutral Protease Activity

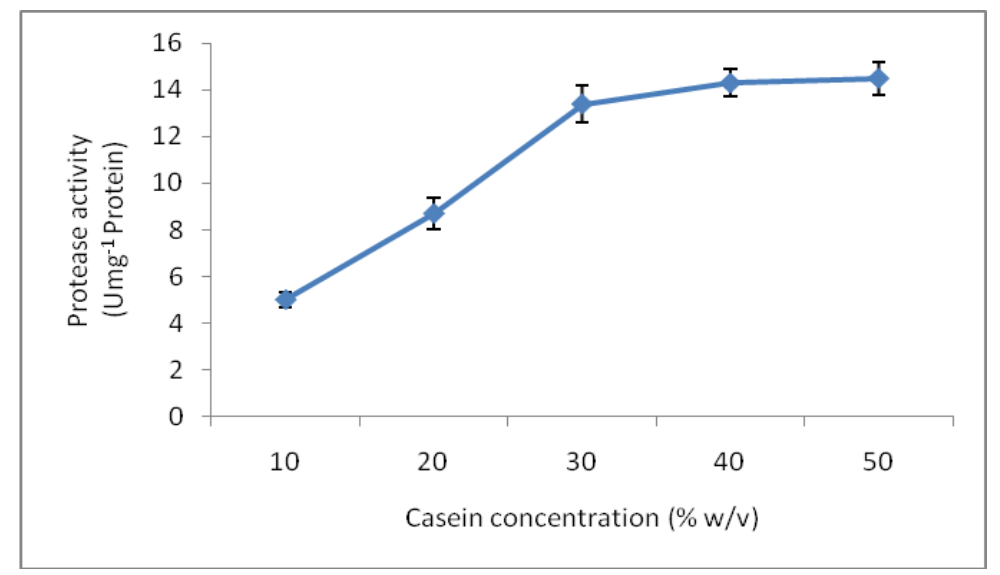

Fig.2 Lineweaver-Burk Double Reciprocalplot for Neutral Protease

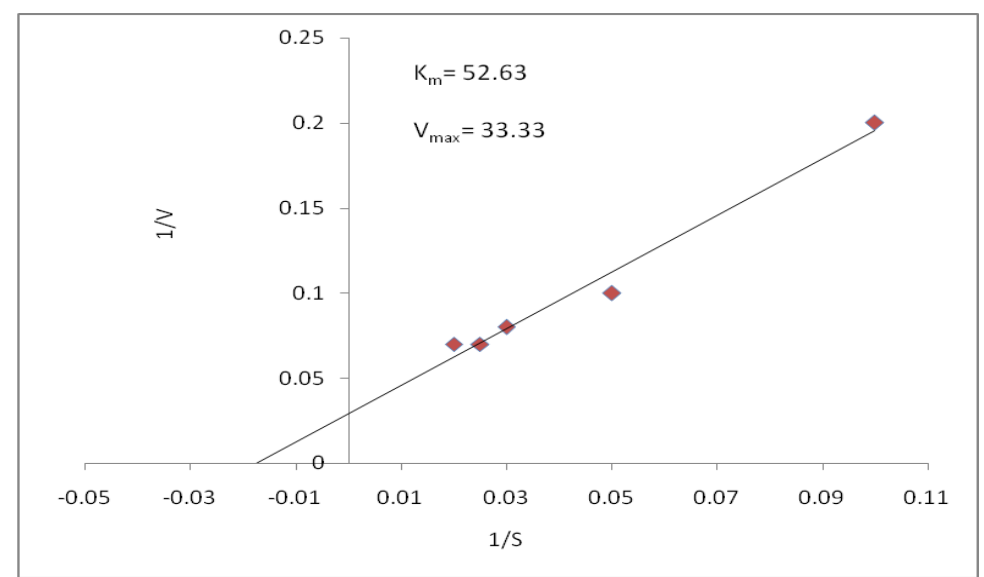


Fig.3 Effect of pH on Neutral Protease

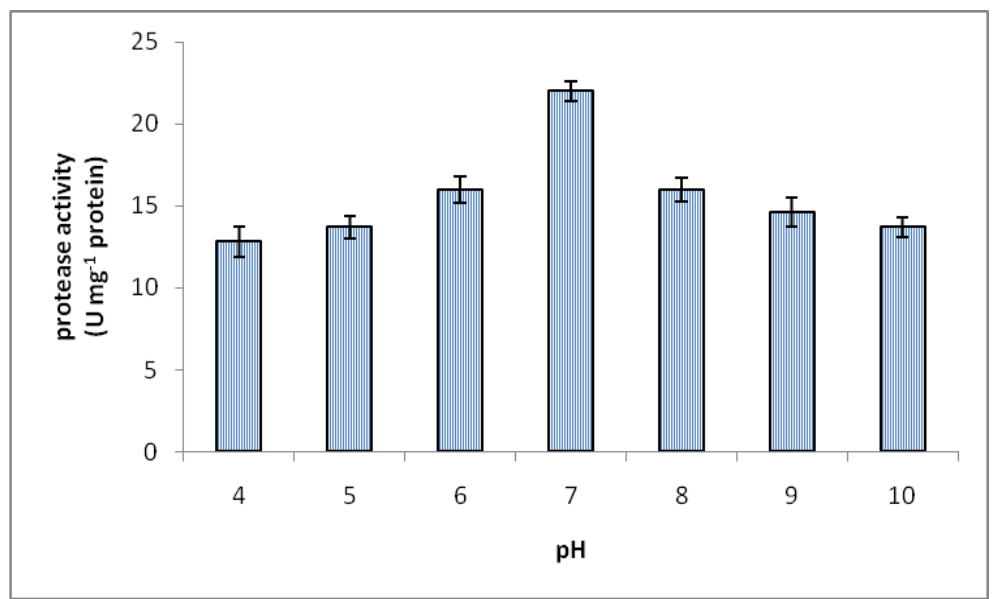

Fig.4 Effect of Temperature $\left({ }^{\circ} \mathrm{C}\right)$ on Neutral Protease Activity

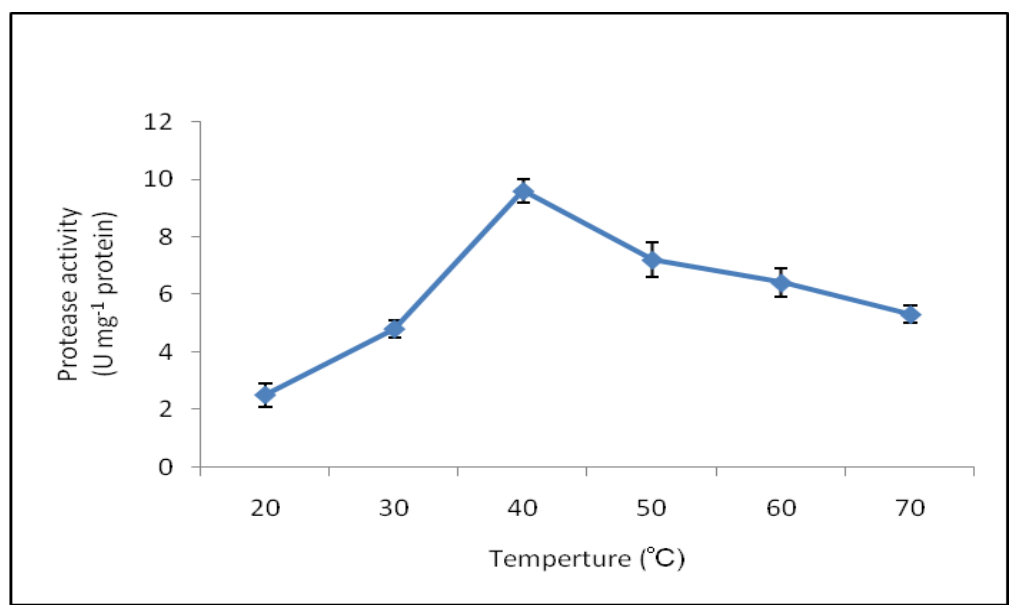

Fig.5 Effect of Incubation Time on Neutral Protease Activity

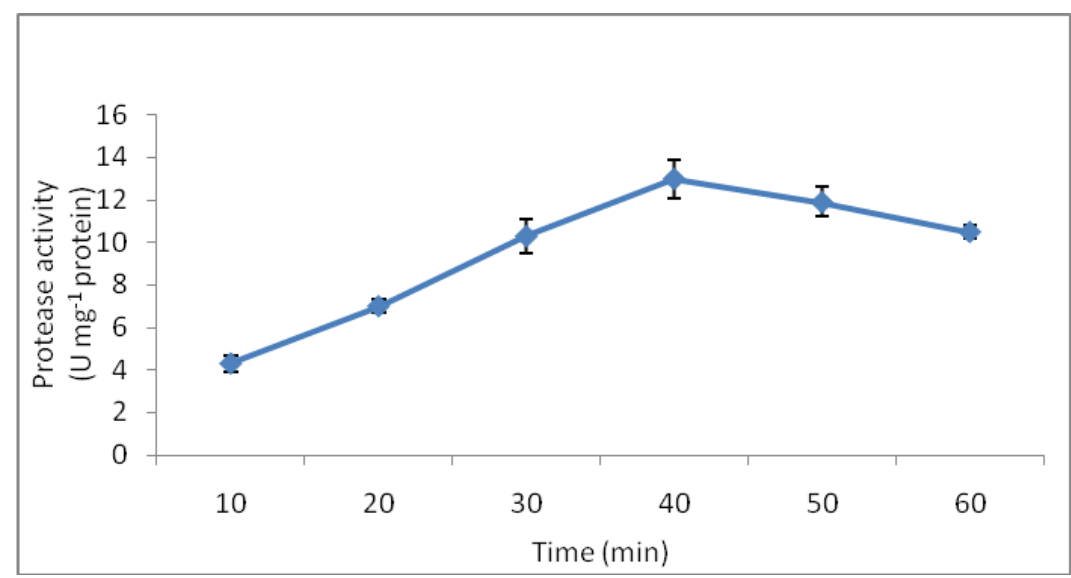


Fig.6 Effect of Metals Ions on Neutral Protease Activity

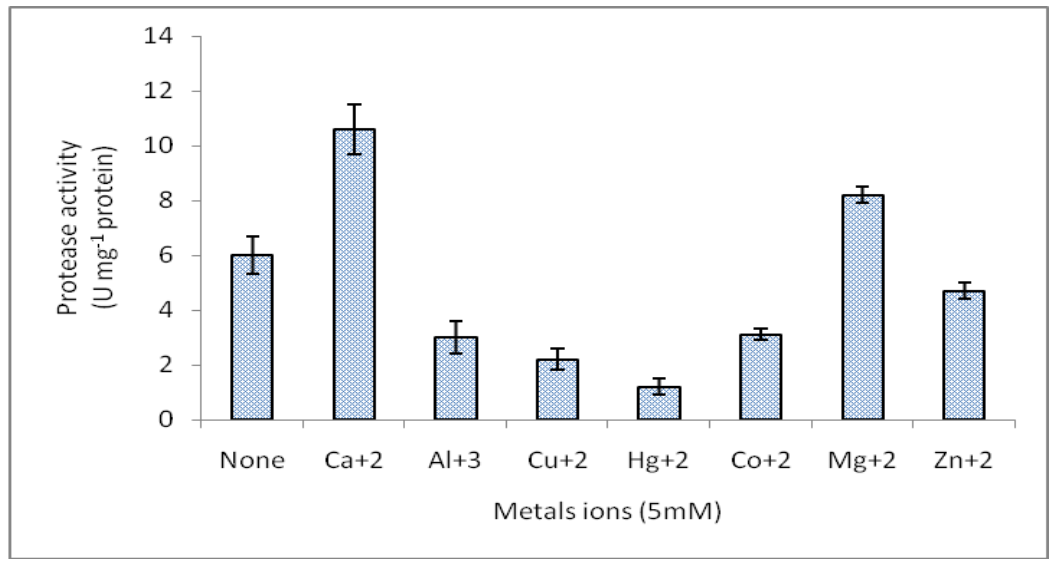

Fig.7 Effect of Some Amino Acids on Neutral Protease Activity

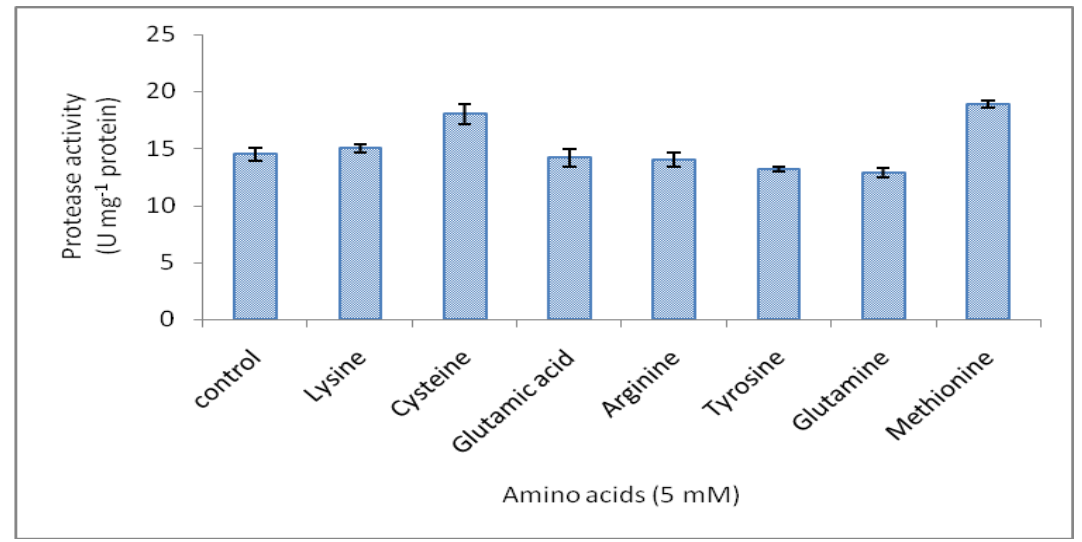

Fig.8 Effect of GSH on Neutral Protease Activity

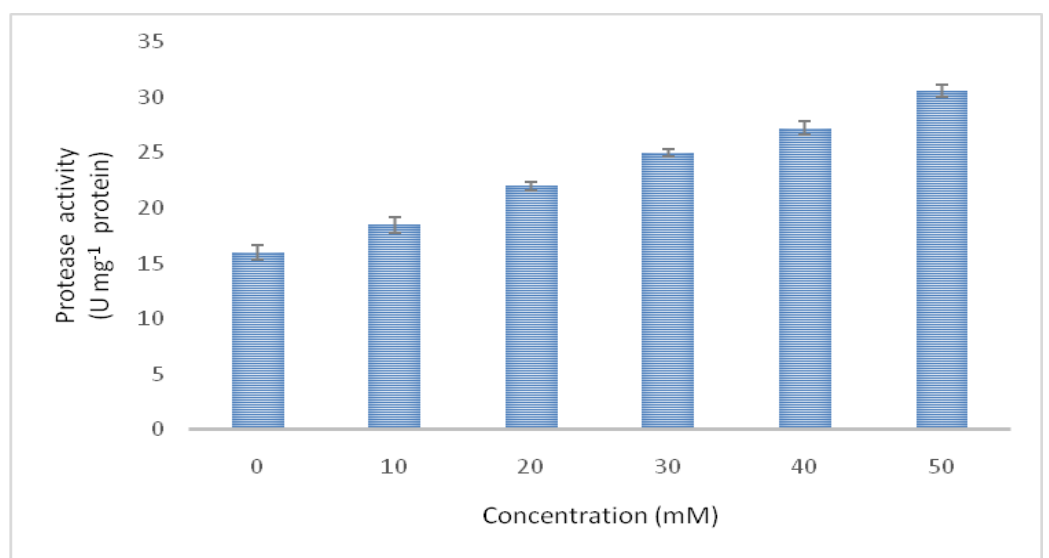


Fig.9 Effect of Thiourea on Neutral pPotease Activity

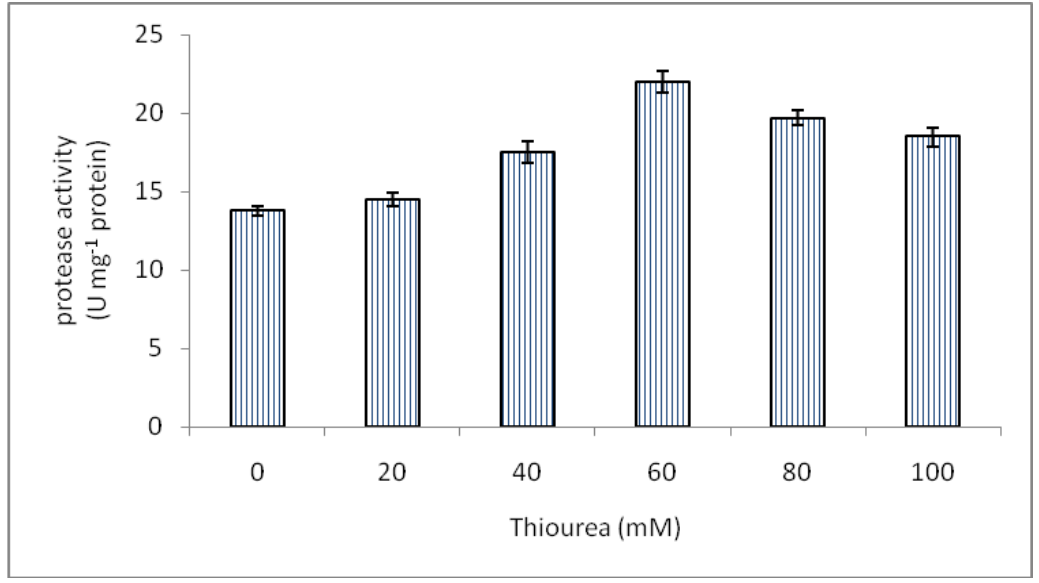

Fig.10 Effect of Thioglycolate on Neutralprotease Activity

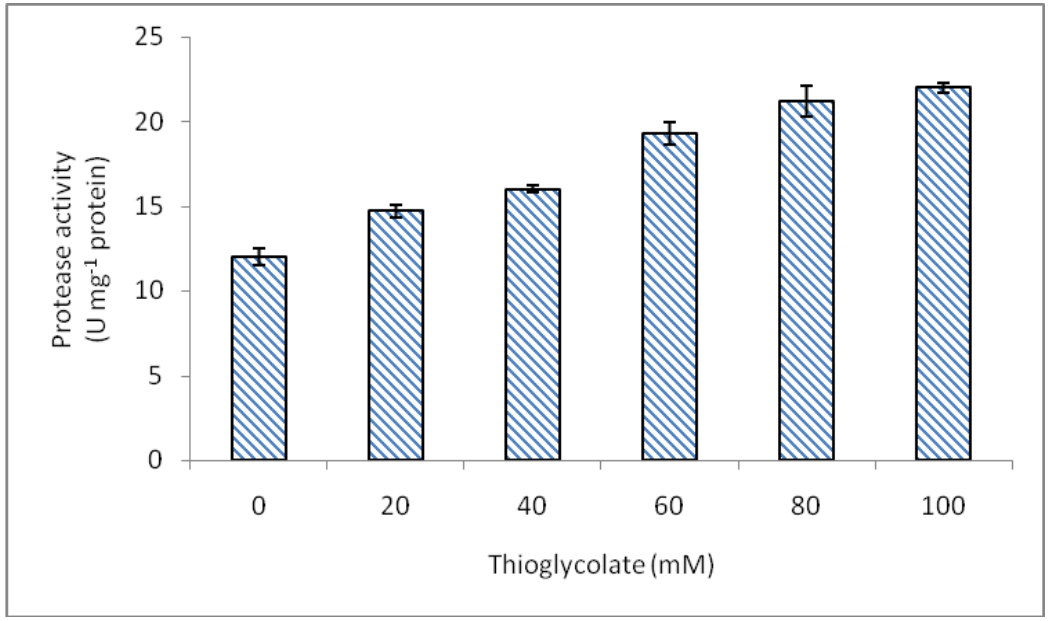

Fig.11 Effect of N-acetyl Cysteine on Neutralprotease Activity

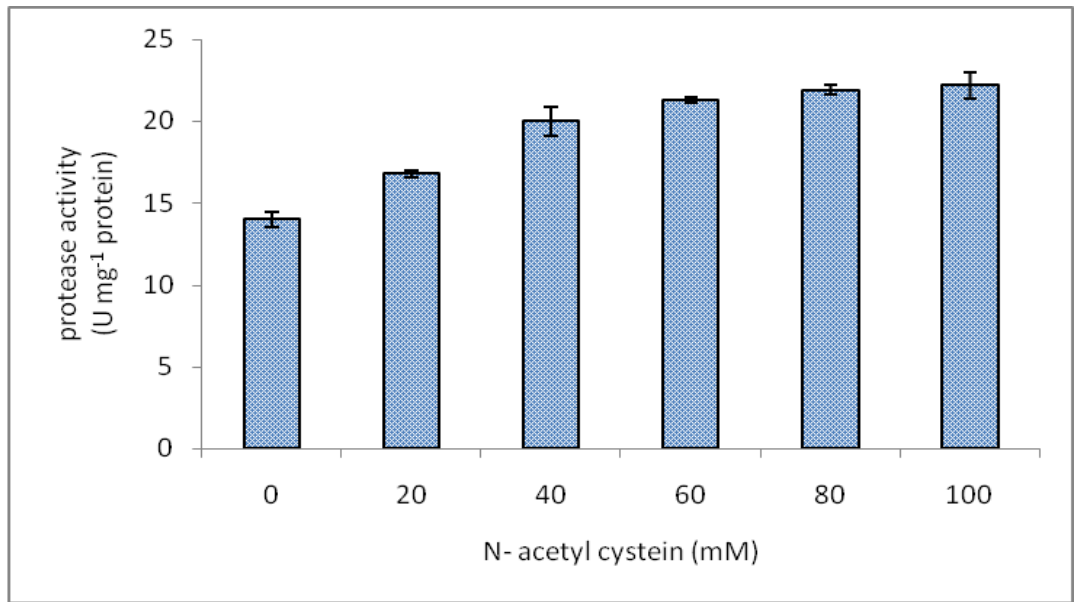


Effect of Various Amino acids on Protease Activity

The effect of various amino acidson protease activity was investigated. The amino acids studeid were lysine, glutamine and methionine. These amino acids were tested at $5 \mathrm{mM}$.The results obtained are shown in Fig.7. These results indicate that cysteine and methionine as sulfhydrylec ontaining amino acid activated the enzyme activity. The activity with these two amino acids were 18.0 and 18.9 units $\mathrm{mg}^{-1}$ protein. Cysteine activated other enzymes such as asparaginase (Warangkar and Khobragade, 2010). The activation by cysteine and methionine also may reveal the importance of these amino acids to protect the enzyme conformation and protect sulfhydryl group. Lysine did not show any remarkable effect on the enzyme.The other remaining amino acids expressed an inhibitory effect varies from one amino acids to the other. The inhibition of protease by the amino acids may be possibly due to competitive inhibition.

\section{Effect of GSH on Protease Activity}

In this experiment the effect of reduced glutathione (GSH) on protease activity was investigated. This compound was tested at various concentration $(10,20,30,40$, and 50 $\mathrm{mM})$.The results obtained are shown in Fig.8. These results show increasing the enzyme activity in concentration-dependent manner. The initial activity was 16 units $\mathrm{mg}^{-}$ ${ }^{1}$ protein which increased gradually up to 30.6 units $\mathrm{mg}^{-1}$ protein at $50 \mathrm{mM}$. GSH activated other enzymes such as asparaginase (Warangkar and Khobragade, 2010). The molecular mechanism behind the activation effects of enzymes by glutathione have been the scope of the investigations for researchers.Enzyme activation by glutathione is not an uncommon event in enzymology. For example, catalytic activity of protease from Schistosoma mansoni(Chappell, 1987), phosphoarginine hydrolase from rat liver (Kuba et al., 2005)and reticulocytic protein kinase (Ernst et al., 1979) were activated by the addition of GSH.

\section{Effect of Thiourea on Protease Activity}

In this experiment the effect of the thiourea on the protease activity at various concentration $(20,40,60,80$ and $100 \mathrm{mM}$ was investigated. The results are shown in Fig.9.These results indicate that there was continuous increase in the enzyme activity to $60 \mathrm{mM}$ where the activity was 22 units $\mathrm{mg}^{-1}$ protein, after which the activity was the enzyme declined. Thiourea activated other enzymes such as asparaginase (Warangkar and Khobragade, 2010).

\section{Effect of Thioglycolate on Protease Activity}

This experiment was carried out to study the effect of various concentrations (20,40,60, 80 , and 100). The results are shown in Fig.10. These results indicate that there was relationship between the thioglycolate concentration corresponding reaction and the enzyme activity. Thioglycolate can activate the enzyme by maintaining the thiol group in the reduced state (Beena et al., 2010).

\section{Effect of N-acetyl cysteine on Protease Activity}

This experiment was designed to investigate the effect of $\mathrm{N}$ - acetyl cysteine on protease activity. This compound was tested at various concentrations $(20,40,60,80$, and $\mathrm{mM})$.The results in Fig.11 show that as the concentration of this compound increased the enzyme activity increased up to 80 units $\mathrm{mg}^{-1}$ protein after which there was steady increase at $100 \mathrm{mM}$. The enzyme was 
activated by thiol-containing compounds including reduced glutathione, thiourea, thioglycolate and $\mathrm{N}$ - acetyl cysteine. The activation by thiol compounds is in harmony with the results of Kamran et al., 2015) who found that mercaptoethanol as another thiolcompound stimulated protease from thermophilic Bacillus sp. This may indicate that SH- group of the enzyme was protected during the incubation time. Also, it is possible that these thiol compounds may lower the $\mathrm{K}_{\mathrm{m}}$ of the enzyme to its substrate and thus activating the activity.

In conclusion, a protease was successfully purified from the Petrocladia capillacea. The optimum temperature and $\mathrm{pH}$ of protease were 7.0 and $40^{\circ} \mathrm{C}$, respectively. Thus, protease could be applied in many industrial purposes. Biotechnological and commercial enzymes such as neutral proteases produced by Petrocladia capillacea are of importance in the food industry. This is because they perform specific functions reducing the bitterness of food protein hydrolysates.

\section{References}

Adinarayana, K., Ellaiah, P. and Prasas, D.S. (2003). Purification and partial characterization of thermostable serine alkaline protease from a newly isolated Bacillus subtilis PE-11. Amer. Assoc. Pharmac. Sci. 4: 440-448.

Ahmetoglu, N., Bekler, F. M., Acer1, O., Guven, R.G. and Guven, K. (2015). Production, purification and characterization of thermostable metallo-protease from newly isolated Bacillus sp. KG5. Eurasia J Biosci 9: 1-11.

Aleem, A.A. (1993). The marine Algae of Alexandria, Egypt. Aleem AA (Ed.) Faculty of Science, University of Alexandria, Egypt.
Annamalai, N., Rajeswari, M.V. and Balasubramanian, T. (2014.) Extraction, purification and application of thermostable and halostable alkaline protease from Bacillus alveayuensis CAS 5 using marine wastes. Food and Bio-products Processing 92: 335-342. http://dx.doi.org/10.1016/j.fbp.2013.08 .009

Banerjee, U.C., Sani, R.K. and Azmi, A. and Sani, R. (1999). Thermostable alkaline protease from Bacillus brevis and its characterization as a laundry detergent additive. Process Biochem., 35: 213219

Beena, P.S., Soorej, M.B., Elyas, K.K., Sarita, G.B. and Chandrasekaran, M. (2010). Acidophilic tannase from marine Aspergillus awamori BTMFW032. J. Microbiol. Biotechnol. 20: 1403-1414.

Bradford, M. (1976). A rapid and sensitive method for the quantitation of microgram quantities of protein utilizing the principle of protein-dye binding. Anal. Biochem. 72: 248-254.

Caliceti, M., Argese, E., Sfriso, A. and Pavoni, B. (2001). Heavy metal contamination in the seaweed of the Heavy metal contamination in the seaweed of the vanice lagoon Heavy metal contamination in the seaweed of the Vanice lagoon. J. Chemosphere, 48: 443-545.

Chappell, C.L., Dresden, M. H. and Walters, D.W. (1987). Glutathione activation of a cysteine proteinase from Schistosoma mansoni, Biochim. Biophys. Acta, 913: 335-341.

Divakar, K, Deepa, Arul, P. J. and Gautam, P. (2010). Purification and characterization of thermostable organic solvent-stable protease from Aeromonas veronii PG01. Journal of Molecular Catalysis B: Enzymatic 66: 
311-318.

Ernst, V., Levin, D.H. and London, I.M. (1979). Inhibition of protein synthesis initiation by oxidized glutathione: activation of a protein kinase that phosphorylates the $\alpha$ subunit of eukaryotic initiation factor 2, Proceedings of the National Academy of Sciences of the United States of America, 75: 4110-4114.

Gupta, S., Cox S., and Abu-Ghannam, N. L. (2011). Food Science and Technology. 44:1266.

Hedstrom, L. (2002). Serine protease mechanism and specificity. Chem Rev., 102: 4501-24.

Hmidet, N., El-Hadj, A. N., Haddar, A., Kanoun, S., Alya, S.K. and Nasri, M. (2009) Alkaline proteases and thermostable $\alpha$-amylase co-produced by Bacillus licheniformis NH1: Characterization and potential application as detergent additive. Biochem. Engin. J. 47: 71-79.

Jellouli, K., Ghorbel-Bellaaj, O., Ayed H.B., Manni, L., Agrebi, R., and Nasri, M. (2011). Alkaline-protease from Bacillus licheniformis MP1: Purification, characterization and potential application as a detergent additive and for shrimp waste deproteinization. Process Biochem. 46: 1248-1256.

Kamran, A., Rehman, H.U, Qader , S.A., Baloch, A.H. and Kamal, M. (2015). Purification and characterization of thiol dependent, oxidation-stable serine alkaline protease from thermophilic Bacillus sp. Journal of Genetic Engineering and Biotechnology. 22(1). DOI: $10.1016 /$ j.jgeb.2015.01.002

Kang, S., Choi, J., Kim, Park, S. and Sapkota, K. (2015). A bifunctional protease from green alga Ulva pertusa with anticoagulant properties: partial purification and characterization. J. Appl. Phycol. DOI 10.1007/s10811015-0550-4.

Kuba, M., Ohmori, H. and Kumon, A. (2005). Characterization of $\mathrm{N}(\omega)$ phosphoarginine hydrolase from rat liver, Eur. J. Biochem. 208: 747-752.

Ladenstein, R. and Antranikian, G. (1998). Proteins from hyperthermophiles: stability and enzymatic catalysis close to the boiling point of water. Adv. Biochem. Eng. Biotechnol. 61: 37-85.

Lopez, I. L., Bastida, S., Cappilas C. R., Bravo, L., Larrea, M. T, Muniz, F. S., Cofrades, S. and Colmenero, F. J. (2009). Composition and antioxidant capacity of low salt meat emulsion model systems containing edible seaweeds. J. Meat. Sci., 83: 492-498.

Maghsoodi, V., Kazemi, A., Nahid, P., Yaghmaei, S. and Sabzevari, S. (2013). Alkaline protease production by immobilized cells using $B$. licheniformis. Scientia Iranica, 20: 607-610.

Murakami, K. et al, (1991). Isolation and characterization of the alkaline protease gene of Aspergillus oryzae. Agric. Biolog. Chem., 55: 2807-2711.

Naidu, K.S. (2011). Characterization and purification of protease enzyme. J. Appl. Pharmac. Sci. 1: 107-112.

Patil, S.S. and Rebecca, L.J. (2014).Isolation and characterization of protease from marine algae. Int. J. Pharm. Rev. Res., 27: 188-190.

Sai-Ut, S., Benjakul, S,P., Sumpavapol, P. and Kishimura, H. (2015). Purification and Characterization of Extracellular Gelatinolytic Protease from Bacillus Amyloliquefaciens H11. J. Food Biochem., 39: 119-128.

Sanatan, P. T., Lomate, P.R., Giri, A.P. and Hivrale, V.K. (2013). Characterization of a chemostable serine alkaline protease from Periplaneta americana. 
BMC Biochem., 14:32.

Sandhya, C., Sumantha, A., Szakacs, G., and Pandey, A. (2005) Comparative evaluation of neutral protease production by Aspergillus oryzae in submerged and solid-state fermentation. Process Biochem. 40: 2689-2694.

Sharmila, S., Rebecca, S. and Saduzzaman, M.D. (2012). Immobilization of plant protease using calcium alginate beads. J. Chem. Pharmac. Res. 4: 4484-4488.
Torres, F A., Passalacqua, T. G., Velasquez, A. M.A., Colepicolo, P. and Graminha, M.A. (2014). Revista Brasileira de Farmacognosia, 24: 265276.

Warangkar, S. .C. and Khobragade, C. N. (2010). Purification, characterization and effect of thiol compounds on activity of the Erwinia carotovora LAsparaginase. Enzyme Research.

\section{How to cite this article:}

Hamed M El-Shora, G.S. Abou-El-Wafa and A.I. Kadhim. 2016. Purification and Biochemical Characteristic of Protease from the Red Seaweed Petrocladia capillacea. Int.J.Curr.Microbiol.App.Sci.5(2): 297-308. doi: http://dx.doi.org/10.20546/ijcmas.2016.502.034 